\title{
Aksi Kamisan: Lamenting Women, State Violence, and Human Security
}

\author{
Mutiara Andalas \\ Prodi Kajian Bahasa Inggris (English Language Studies) Universitas Sanata Dharma \\ Email: mutiaraandalas@usd.ac.id
}

\begin{abstract}
This paper investigates the relationship of Aksi Kamisan and human security. It narrates the phenomenon of women participating in Aksi Kamisan who lament silently before the Presidential office. It explores the essential contribution of these women parading in front of the government offices in promoting human security. Women participants of Aksi Kamisan choose lamentation as a persuasive language to deliver messages on the importance of human security. Analyzing their letters sent to the present President and listening to their oral testimonies, I systematize their previously implicit understanding of human security. In the process I expose the underlying theology of the so-called 'god of security' by regimes after the reformation era. Finally I reflect on the theme from the historical-feminist-theological perspectives finding deeper meaning in the pursuit of truth and healing in the face of human suffering.
\end{abstract}

Keywords: aksi kamisan, lamentation, god of security, human security

Tulisan ini menelisik hubungan antara Aksi Kamisan dan keamanan manusia (human security). Ia mengisahkan fenomena para perempuan yang terlibat dalam Aksi Kamisan dengan ratapan di depan istana negara. Ia mengeksplorasi kemungkinan sumbangan para perempuan ini dalam diskusi tentang keamanan manusia. Mereka memilih ratapan sebagai bahasa yang persuasif untuk menyampaikan pentingnya keamanan manusia. Menganalisis surat-surat kepada para presiden dan mendengarkan kesaksian lisan mereka, saya mengabjadkan pemahaman implisit mereka tentang keamanan manusia. Pada saat bersamaan, saya membongkar teologi 'illah keamanan' yang rezim-rezim setelah era reformasi memeluknya. Saya merefleksikan tema ini dari perspektif historis-feminis-teologis untuk mendalami keamanan dihadapan penderitaan korban.

Kata Kunci: aksi kamisan, ratapan, illah keamanan, keamanan manusia.

\section{Background of the Study}

When participants held Aksi Kamisan for the first time, they immediately caught my attention. Joining the Volunteer Team for Humanity, I had assisted families of past victims of human rights violations and abuse survivors visiting government offices. At the government offices they orally delivered petitions to government officials and sent written letters at the end of the rallies. There I encountered some women participants who later pioneered Aksi Kamisan. Different from previous rallies before the government offices, participants of Aksi Kamisan choose to deliver their petitions to the President in silence. Rather than seeing it as a weakness, I see silence as a persuasive language addressed to the state, a form of "muted dissent". I am particularly interested in analyzing the essential contribution of these leading women in enriching the discussion of human security.

Aksi Kamisan is an act of standing silently in front of the State Palace and delivering a petition to the Indonesian President for settling human tragedies pioneered by the Solidarity Network of Victims for Justice. Learning from similar women's movements across the globe, such as the Mothers of Plaza de Mayo, they promote 
human security by resisting against regimes that worship the 'god of violence'. Starting from the domestic space, which is often synonymous with the role of women at home and taking care of their families, they step into the political sphere. The Solidarity Network of Victims for Justice believes that human tragedies dislocate society. They see the importance of raising prophetic voices about human tragedies to promote human security. Human tragedies displace a regime's previously established certitude as the sole actor in providing national security.

Studies on Aksi Kamisan, or about the promotion of human security by the Solidarity Network of Victims for Justice, are still rare in numbers. The rarity is partly because of the difficulty for researchers to systematize their lamentation. Their language is more 'poetic' and less 'prosaic' with empty spaces in-between. The second difficulty is in seeing the relevance of their narratives in the post-authoritarian Indonesia. The third difficulty is relating Aksi Kamisan to the global issue of human (in)security. This paper inquires about the following question: How do lamenting women both resist state violence and promote human security? Applying the historical-feminist-theological perspectives, I narrate the metamorphosis of the Solidarity Network of Victims for Justice from a less organized group into an organized international movement that promotes human security. In the process, I discovered that the essence of what is sacred to human life is at stake and is in jeopardy of becoming lost and forgotten in the modern society's push to go beyond human suffering and leave in the past the essential need for healing through forgiveness and recognition of the value of true reconciliation.

\section{Literature Review and Theoretical Framework}

Due to my limited ability in finding academic works on Aksi Kamisan, I humbly share my personal journey of discovery in writing about it. My close encounters with families of the victims of 1998 have helped me in better understanding the group named Aksi Kamisan. My early writing on Aksi Kamisan paid attention to embryonic ideas among the first participants that gave birth to the movement. I listened to pioneers who initiated Aksi Kamisan. I also investigated their choice of the Presidential office as the place for delivering petitions. My later writings visualized the current state that silences their voice as the "republic of violence". I searched for inspirations from similar movements around the world to better understand silent lamentation as a language of "muted dissent" to persuade listeners. I also reflected on the political engagement of these women in shaping the democratic sphere in Indonesia through Aksi Kamisan. ${ }^{1}$

\footnotetext{
${ }^{1}$ Mutiara Andalas, "Kata Tak Lagi Bermakna Kini! Aksi Kamisan, Negara Kriminal \& Teologi Politik", dalam Lahir dari Rahim: Wacana Perempuan Asia tentang Allah di Era Globalisasi (Yogyakarta: Kanisius, 2009), 260-84; Ibid., "Salib Sejarah", "Sejarah Tanpa Paras Korban", "Ecce
} 
Relating Aksi Kamisan to human security is an academically pioneering project. It inquires about the essential contribution of women participants joining Aksi Kamisan in promoting human security. Rather than simplifying the issue, I consider it as a complex one because the promotion for human security involves not only participants of Aksi Kamisan. It also involves other political subjects, especially the policies of the current regime. The issue even becomes more entangled because it deepens our visualization of the regime without demonizing it. Under the Soeharto regime, Indonesians lived under the totalitarian State that played 'Almighty God'. Playing god, the reigning regime created precariousness in the lives of people. Regimes after Soeharto era still lamentably play god although they do so less faithfully.

I am academically indebted to Judith Butler for her sharing better understanding of women participants of Aksi Kamisan who make use of silence to struggle against victim silencing. Butler also helps me to comprehend the regime's injurious speech toward the innocent victims. She emphasizes human existence as "linguistic beings". Responding to the phenomenon of "injurious speech", she further discusses "linguistic vulnerability" in depth. She explains how words and their

Homo: Kebisuan Negara, Pembisuan Korban, \& Politik Kenangan", dalam Penyair Kebenaran di Republik Kekerasan Prolog: Ester Jusuf, Epilog: Suciwati dan Maria K. Sumarsih (Yogyakarta: Kanisius, 2012), 6-17, 27-34, 92-100; Ibid, “Aksi Kamisan: Ratapan Perempuan, Kriminalitas Rezim \& Ruang Demokrasi”. linguistic representations can sustain the body. At the same time they can threaten its existence. Addressing a name can injure others when certain individuals or groups misuse it to derogate the addressee. At the same time, addressing someone with a name can bring social existence to the addressee. ${ }^{2}$ Butler continues this discussion of language and the power of naming by explaining the following:

Clearly, injurious names have a history, one that is invoked and reconsolidated at the moment of utterance, but not explicitly told. This is not simply a history of how they have been used, in what contexts, and for what purposes; it is the way such histories are installed and arrested in and by the name. The name has, thus, a historicity, what might be understood as the history which has become internal to a name, has come to constitute the contemporary meaning of a name: sedimentation of its usages as they have become part of the very name, a sedimentation, a repetition that congeals, that gives the name its force. ${ }^{3}$

\footnotetext{
2 Judith Butler, Excitable Speech: A Politics of the Performative (New York, NY: Routledge, 1997), 140.

${ }^{3}$ Judith Butler, Excitable Speech: A Politics of the Performative, 36.
} 
Jon Sobrino helps me in naming contemporary gods acting against God in political sphere. They act against God, dehumanize those who render them homage and need victims in order to survive ${ }^{4}$. Jesus not only proclaims the Kingdom and proclaims a Father God; he also denounces the antiKingdom and unmasks its idols. In doing so he strikes at the roots of a society oppressed by all sorts of power: economic, political, ideological and religious. The anti-Kingdom exists and Jesus, objectively, gives an account of what its roots are. And he is not content with denouncing the Evil One, a trans-historical reality, but denounces those responsible for the anti-Kingdom, who make up truly historical reality.

\section{Lamenting Women}

My first encounter with lamenting women took place in sites of tragedy. They sanctify these sites as places to pray to God. I met some of them afterwards at gatherings where they planned actions to pursue justice for the innocent victims. Gathering places become sites for mutual support psychologically, politically, and even economically. They shared stories of visiting government offices to know the progress of their cases. They realized the great difficulty in petitioning their cases individually. They also

\footnotetext{
${ }^{4}$ Jon Sobrino, Jesus the Liberator: A HistoricalTheological Reading of Jesus of Nazareth, Translated from the Spanish by Paul Burns and Francis McDonagh (Maryknoll, NY: Orbis Books, 1994), 174.
}

recognize that government officials generally tended to dismiss them. They consider it important to strengthen their struggle by forming a network in its simplest form. They also search for alternatives to encourage the government officials in settling past human rights violations.

In the absence of the victims, participants of Aksi Kamisan are, in a way, living museums that commemorate the deceased. It is a difficult experience of losing loved ones in such tragic circumstances. It is even more difficult to tell stories of losing them. Essentially, it takes time for them to finally stand before the public. For sometimes they make meaning of it before giving testimony to the public. It takes courage for them to testify about losing their beloved. One participant in Aksi Kamisan expressed the following gratitude for the action network:

$$
\begin{aligned}
& \text { I tried to ponder it [the } \\
& \text { premature death of my son]. I } \\
& \text { conclude wholeheartedly that } \\
& \text { it [his premature death] is not } \\
& \text { just destiny, but there is a } \\
& \text { mystery that veils it. I have to } \\
& \text { reveal this mystery. I had to do } \\
& \text { something. I'm thankful that } \\
& \text { I'm not alone in this grief. } \\
& \text { Many friends care about our } \\
& \text { family. }
\end{aligned}
$$

\footnotetext{
${ }^{5}$ Suciwati Munir, "Munir: Cahaya yang Tak Pernah Padam" dalam Jaringan Solidaritas Korban untuk Keadilan, Saatnya Korban Bicara: Menata Derap, Merajut Langkah (Jakarta, JKT: Yayasan Tifa,
} 
Aksi Kamisan started with small numbers, yet committed participants continue to sustain its continuity. Basically, they imagine not rallying in big numbers, but they are open to the presence of others joining Aksi Kamisan. If there were only three of them, as in the joining of the first pioneers of Aksi Kamisan, they would continue it. Starting with a small number of participants, they prepare for Aksi Kamisan. They share responsibility in writing letters to the President as a closing part of Aksi Kamisan. They also rotate members to speak to the media who do coverage of their action. Raising consciousness that all participants are important members of the network, they have learned to share the responsibility, and furthermore the leadership. The powerful examples of the Mothers of Plaza de Mayo inspire them in carrying out Aksi Kamisan as faithful as possible.

Lamentation becomes the peculiar mode of women participants of Aksi Kamisan in telling their personal tragedy to the wider society. For many it takes longer time to finally speak before the network. Some needed to pass through difficult times, even trauma because of losing their beloved. Because traumatic events easily disable their language, they need time to systematize their testimony. It often combines not just words, but words and silence. They have searched for the safe place, even opened spaces for testimony.

Jaringan Relawan untuk Kemanusiaan, Jaringan Solidaritas Korban untuk Keadilan, 2009), 11.
Starting with close friends, they widen the audience by giving testimony to a more general audience. They have realized that an audience tends to have a short memory of their own personal history. Despite the power of testimony to touch people's heart, their testimonies grievously speak less over time. They do not yet transform the audience into solidarity with the grieving victims.

After lamenting at sites of tragedy and at home, they visit government offices to seek truth. They find the unnatural death of the beloved grievous. Rather than simply accepting it as the will of God, their restless heart leads them to investigate the perpetrator of violence that causes unjust death. They find strength when they build a network rather than investigating it and standing alone. The death of the loved one transforms home from a previously apolitical sphere into a site for struggle and grievance. The lamenting women have transformed themselves from more domestic individuals to political subjects. When people address them as activists, they see themselves more as a sister, mother, wife or grandmother. Many still maintain the balance of having one foot in a domestic sphere and the other in the public sphere. Walking in both worlds, the Presidential office becomes the last address for searching for truth.

When human tragedy hit their lives, their first thought was sharing it with the state officials. They wait in line to have an audience with him. At first they fully trusted that the 
state would listen emphatically when they spoke to them. They innocently believed that he would renew his commitment in guaranteeing human security. They learned that they needed to wait in line before speaking to government officials. Without having a prejudice against state officials, they thought that sending letters might work better. For most of the time, they waited for the replies. Meanwhile the police often barricade these offices from the danger of solicitation when they tried to meet them. They needed first to cross the barricade before entering their offices. Without compassion, many government officials show indifference and apathy toward their cases.

Conducting Aksi Kamisan, participants demand the President to acknowledge past human rights violations and bring justice to them. They choose lamentation as a powerful language to testify historical tragedies before the public. Post-reformation regimes have promised to settle past human rights violations during their reigning times. All share the similarity in breaking their promise. Responding to their indifference, participants of Aksi Kamisan search for an alternative language to awaken the state's compassion. In its fullest metamorphosis lamentation transforms into silence, into muted dissent. They consider silence as possibly the last available language to plea for justice for the deceased. They finally adopt this specific type of language because the state has injured them twice by denying past historical tragedies and ignoring their testimonies.

\section{State Violence}

The discussion about state violence seems to lose its relevance after the Reformation era. Many think that a reformation era instantaneously shifts regimes from authoritarian to democratic ones. By fulfilling all administrative requirements, a regime calls itself as democratic procedurally. Since all regimes afterwards claim themselves as democratic, we need to measure it more than just procedurally, but by the degree of embracing it. Responding to the question whether changes are cosmetic or radical, participants of Aksi Kamisan offer us what I call "political catechism" in helping us in answering this inquiry. They guide us step by step to measure the degree of democracy practiced by certain regimes. They further escort us in knowing the anatomy of state violence.

The proposal of forming the Truth and Reconciliation Commission becomes a great test case to investigate the sincere commitment of post-reformation era regimes in securing humanity. The state encourages the formation of the Truth and Reconciliation Commission. He thinks that it is time now to reconcile, not task for truth about past human right violations. On the contrary, participants of Aksi Kamisan show indifference in receiving the offer. We often misunderstand their refusal to accept this proposal. The refusal seems to be 
irrational because participants of Aksi Kamisan wish it. The regimes also judge them as ones who prevent human security from happening in the post-reformation era. We need to see it more comprehensively by systemizing the way the state understands truth, reconciliation, and human security.

The state believes that naming the perpetrators of past human rights violations that caused premature death, further bringing them to justice, is unnecessary for reconciliation. He indicates that he can skip this pathway and leap directly into reconciliation. The reluctance on the part of the state makes him impossible in the eyes of participants of Aksi Kamisan to change his past habit of orchestrating violence that injured others. The failure to confess past human rights violations puts at risk his objection to ask forgiveness from those who are injured by his violence. The acceptance to cooperate with the Truth and Reconciliation Commission will not make any changes to the society when he does not change his habit of injuring others. The problem lies more not on the party who needs to forgive but on the willingness of the party who needs to ask for forgiveness.

Some may think that the state and participants of Aksi Kamisan look at the Truth and Reconciliation Commission (TRC) from different perspectives. Instead of a different perspective, I see it as a contrasting one. The state believes that the Truth and Reconciliation Commission is first and foremost an effort at reconciliation. This belief seems to have no problem in so far as the prioritization of reconciliation notices truth. The problem stems from the separation of reconciliation from truth. On the contrary, participants of Aksi Kamisan see the impossibility of understanding reconciliation that suppresses truth. They believe that reconciliation will only receive its full meaning when we relate it to truth. They strongly reject the state's proposal of the Truth and Reconciliation Commission because of this dichotomizing of reconciliation and truth.

Desmond Tutu and Mpho Tutu enrich us about acknowledging past violations by providing an inspiring biblical text through the character of Jesus. Instead of erasing stigmata in the body, the wounds of Christ emphasize the importance of bringing violence into the light of truth:

Jesus, the Son of God, could erase the signs of leprosy; heal those broken in body, mind, or spirit; and restore sight to the blind. He must also have been able to obliterate the signs of the torture and death he endured. But he chose not to erase that evidence. After the resurrection, he appeared to his disciples. In most instances, he showed them his wounds and his scars. This is what healing demands. Behavior that is hurtful, shameful, abusive, or 
demeaning must be brought into the fierce light of truth. ${ }^{6}$

The problem lies in the false conviction of the state as a perfect institution. He allows not imperfection, but further error in his action toward others. $\mathrm{He}$ often dichotomizes state and people. In its fullest form, the state denies the charge of atrocities done and without redress victimizes all who challenge it. They find reason to justify their action as faithful to the highest order. They act according to the dogma of procedure. From his perspective, he is not a villain, but the hero, worthy to be worshipped. He acknowledges not atrocity against the victims, but remains as the unforgiven when he prolongs denial and he sees not any need for asking for forgiveness. They are unwilling to search out the victims' and survivors' humanity. Since they see themselves as politically innocent, they are unwilling to ask for reconciliation.

Maria K. Sumarsih, one participant of Aksi Kamisan, eloquently exposes the adulteration of law by the state to grant impunity toward perpetrators of human right violations. She explains that institutional violence by the state continues in more subtle and covert means:

It is too naive that the state so easily takes over grave human right violations from

\footnotetext{
${ }^{6}$ Desmond Tutu \& Mpho Tutu, The Book of Forgiving: The Fourfold Path for Healing Ourselves and Our World (New York, NY: HarperCollins, 2014), Ch. 1.
}

perpetrators: there is no guilt among perpetrators, it is inclined to recurrence, and it grants impunity to the perpetrators.

.... We need to remember that we have law to regulate the settlement of human right violation: Law No. 26/2000 on human right violation. The problem is not that that the law is powerless, but there is a deliberate intention to make it ineffective. This deliberate intention is paired with impunity. ${ }^{7}$

Participants of Aksi Kamisan realize that the succeeding regimes have broken their promise. They provide impunity by omitting the cases passed by for years. They indirectly provide impunity toward perpetrators of past human rights violations. This political gesture endangers the future of Indonesia. By putting people's lives in a precarious situation, they play a dangerous game of "Truth and Consequences". Although settling past human rights violations looks like a small factor in comparison to other great achievements in the post-reformation era, it is an important determinant in my imagining an accurate vision of the current state. The adoption of

\footnotetext{
7 Maria K. Sumarsih, "Pelanggaran HAM dan Minta Maaf" dalam Mutiara Andalas, Penyair Kebenaran di Republik Kekerasan, Prolog: Ester Jusuf, Epilog: Suciwati dan Maria K. Sumarsih (Yogyakarta, YK: Kanisius, 2012), 349-50.
} 
violent ways in governing society forces people to live in a precarious situation. This coercion is not just a single act separated from other acts. I see it as part of a political creed, even a certain 'theology' related to security.

The official story about past human right violations blurs the facts. They conceal the number of victims, or at least derogate it. They even succeed in confusing ordinary people about the truth of historical events. The state lacks the commitment to settle the cases. At the subordinate level, participants of Aksi Kamisan have witnessed the impotence of law enforcers in bringing perpetrators of human rights violations to acknowledge their offenses and give justice for the victims. The perpetrators even arrogantly rejected the call to justice. When the court succeeded to bring the accused to the court, he grants him innocence. Witnessing custody given by the state and impunity granted by the court to these perpetrators, participants of Aksi Kamisan inquire into alternative ways to bring justice for the victims.

At the grassroots level, the state propagandizes "national amnesia." Instead of catechizing future generations about past human rights violations, he has shortened the memory of people about the past. History class syllabi have been designed to exclude materials related to past human rights violations. Students find difficulty to find learning materials about them in the assigned history books. Enthusiastic history teachers need to find alternative materials when they want to teach those topics. When participants of Aksi Kamisan socialize alternative sources for renewing history class materials, the hardliners who claim to receive nationalistic calling to maintain social order threaten them. Any initiatives to awaken historical consciousness about past human rights violations often suffer forced dispersal and derogation.

After reviewing the consistent ways regimes maintained after the reformation era in managing past human rights violations, I summarize their theology. They subconsciously worship what I call the "god of security". All join liturgy in confessing faith in this god. Security becomes a sacred dogma for this worshipping community. They sanctify security, even themselves, at the level equal to God. Playing god, they always find justification in their actions. In the name of securing security, they innocently carry out violence. Instead of understanding it as threats against human security, all participants see violence toward others as devotion toward this so-called god of security. The opposite of "god of security" is actual "human security". Antithetically, human security is a critique to the worshipping of this "god of security".

Similar to religion, this worshipping of the god of security has its celebration. Their liturgical calendars show festive and ordinary times throughout the year. It commemorates "saints" who live the faith in the god of security extraordinarily. They have priests who lead the celebration and a high priest as their 
leader. They preach about the importance of having faith in the god of security. They lead the whole congregation to confess faith in the god of security. After celebration, the celebrant sends them to evangelize the god of security to people who are strangers still to him. Dissimilar to true religion, the faith in the god of security requires human victims as offertory for the celebration. In the name of the god of security, they further carry out violence toward individuals or groups of people who challenge their faith.

\section{Human Security}

Precariousness of life, as participants of Aksi Kamisan lamented it, becomes my starting point in discussing human security. The loss of the loved ones and their solidarity toward other victims of state violence encourage them to promote human security. The purpose of this discussion hopefully engages the state to end their worshipping of the god of security. In the previous section, I exposed different devious ways, derived from one faith in worshipping the god of security. Even when succeeding regimes derive some benefits limitedly from it, we should be alert to its danger. Violence against victims and survivors of past human rights violations challenge us to discuss human security both with a sense of importance and an immediate urgency. The main purpose of discussing it secures Indonesians, especially the innocents, from its eminent danger.
Precariousness of life needs further exploration to better comprehend human security. Regimes take limited actions when perpetrators of violence annul their lives. They do not guarantee the people's safety before perpetrators of violence who threaten their lives. The lack of responsibility happens when they undermine the importance for discussing further the precariousness of life. At the same time, in the name of securing order in the society, they carry out violence as a necessary action toward individuals or groups who potentially threaten it. The absence of regimes' protection puts ordinary civilians in a precarious situation of becoming easy targets of human rights violation. At the grass roots level, ordinary citizens internalize it by applying self-censorship to activities that they personally perceive as likely threatening their 'security' as the regimes define it.

The violation of human rights is, according to my perception, an antithesis of human security. We understand human security first of all as protection toward vulnerable individuals and groups from precarious situations. Human protection handles protection toward the most basic right of humans, the sacred right of life. Different from previous regimes, post-reformation era regimes claim not to be authoritarian. They embrace democratic principles procedurally. They explicitly claim to promote human security by prioritizing the settling of past human rights violations. Participants of Aksi Kamisan implicitly emphasize the importance 
of human security. Philosophically, true human security will flourish if the state ends in worshipping the god of security. A true national reconciliation takes place when the state takes truth about past human right violations seriously.

Promoting human security is a great challenge when many believe in the 'one and only' god of security. Many individuals and mass organizations adopt its theology by justifying the use of violence to maintain societal order. Contemporary theologians of this god have tried to convince us that there are no alternatives other than embracing the god of security. Christ spoke counter intuitively about this hierarchy when he explained to the Disciples the following insight:

Jesus called them together and said, "You know that the rulers of the Gentiles lord it over them, and their high officials exercise authority over them. Not so with you. Instead, whoever wants to become great among you must be your servant, and whoever wants to be first must be your slave-just as the Son of Man did not come to be served, but to serve, and to give his life as a ransom for many" (Matt 20, 25-28).

Regimes who believe in the god of security live above the law. They even become the law. They arbitrarily misuse law to secure his political position. When there are options of securing his position or human life, he sacrifices the later. He neglects individuals or groups who take initiative to promote human security because they threaten his faith in the god of security. To secure humans from living in a precarious position, regimes need to break away from this god of security. Human security should become the new law for the regimes in governing their citizens in order to truly protect their lives. I underline the important role of lamenting women in promoting human security by exposing, and further challenging the god of security worshipped by regimes especially after the post-reformation era.

Suciwati, whose beloved husband Munir was murdered with arsenic while on a flight, shares her commitment as a human rights defender. She shares strategies among human rights defenders to improve human security by explaining the following:

Naturally, right defenders all over the world do not remain silent. They have adopted a series of strategies to protect individuals against risks and improve the security of their environment as a whole. It is done, among others, by creating a protection mechanism for nongovernmental circles, providing prompt legal 
assistance or medical aid in cases of attacks and relocations and building an international advocacy network. $^{8}$

\section{Conclusion}

Love toward the victims and survivors of past human rights violations becomes a starting point for participants of Aksi Kamisan to promote human security. They lamented for quite sometime because of losing their beloved. They honored the dead by burying them as respectfully as possible. When they marched to the government offices, they brought pictures and other memorabilia. Even after their death, they recovered their dignity when regimes stigmatized them as "plunderers", "demonstrators", "communists", and other derogatory identities. They reclaim the dead as truly good people, even holy humans in the primordial sense. Instead of accepting the fate of the deceased, they seek to reveal the previous mystery that caused their suffering.

The next step in this inquiry investigates post-reformation regimes' attitudes toward human security. Despite good efforts to procedurally embrace democratic principles, they implicitly have worshipped the "god of security". Regimes that have treated security as the highest law actually threaten human security. Instead of securing humanity,

\footnotetext{
${ }^{8}$ Suciwati Munir, "Right Defenders: Your Fate Today Is Your Choice", Jakarta Post, March 8, 2010.
}

pleasuring security as the highest law causes insecurity, even premature death. Regimes position themselves as equals with God in politics. They play god toward citizens whose identities threaten national security. Promoting human security, according to participants of Aksi Kamisan, requires critique toward regimes that worship the god of security. It requires regimes to break this faith on the god of security and embrace true human security.

Women parading silently in front of the Presidential office provide us with a sense of importance and urgency in discussing human security. They highlight the importance of honoring the dignity of humanity starting from giving justice for victims and survivors of past human rights violations. People will live precariously and even suffer premature death when regimes exclude efforts in securing humanity, and instead only embrace the god of security. Sustaining social order starts with protecting innocents living a precarious situation. Settling past human rights violations signifies their commitment to promote human security. The promotion of human rights lives at the heart of human security. The spirit of the reformation era hopefully ignites at least the current regime to truly embrace human security. 


\section{References}

Andalas, Mutiara, Lahir dari Rahim: Wacana Perempuan Asia tentang Allah di Era Globalisasi (Yogyakarta: Kanisius, 2009)

Penyair Kebenaran di Republik Kekerasan, Prolog: Ester Jusuf, Epilog: Suciwati dan Maria K. Sumarsih (Yogyakarta: Kanisius, 2012)

Butler, Judith., Excitable Speech: A Politics of the Performative (New York, NY: Routledge, 1997)

Jaringan Solidaritas Korban untuk Keadilan (JSKK)., Saatnya Korban Bicara: Menata Derap, Merajut Langkah
(Jakarta, JKT: Yayasan Tifa, Jaringan Relawan untuk Kemanusiaan, Jaringan Solidaritas Korban untuk Keadilan, 2009).

Munir, Suciwati., "Right Defenders: Your Fate Today Is Your Choice”, Jakarta Post, March 8, 2010.

Sobrino, Jon Jesus the Liberator: A HistoricalTheological Reading of Jesus of Nazareth, Translated from the Spanish by Paul Burns and Francis McDonagh (Maryknoll, NY: Orbis Books, 1994), 174.

Tutu, Desmond \& Mpho Tutu, The Book of Forgiving: The Fourfold Path for Healing Ourselves and Our World (New York, NY: HarperCollins, 2014). 